\title{
EL DECOMISO DE BIENES DE TERCERO EN ESPAÑA Y COLOMBIA*
}

\author{
THE SEIZURE OF THIRD-PARTY ASSETS IN SPAIN \\ AND COLOMBIA
}

José Felipe Cuero Solís**

\section{Resumen}

Para nadie resulta extraño que los delincuentes busquen encubrir los activos producto de sus actividades ilícitas, de tal forma que puedan disfrutar libremente de los mismos y, para ello, en ocasiones, se valen de terceros; por esto, la persecución de los activos originados ilícitamente ha logrado un protagonismo sin precedentes en las últimas décadas. A tono con lo indicado, el presente trabajo se propone, por un lado, analizar las figuras del decomiso de bienes de terceros en la legislación española tras la reciente reforma operada al Código Penal, mediante la L.O. 1/2015, de 30 de marzo, al igual que de la acción constitucional de extinción de dominio colombiana; y, por el otro, dejar en evidencia las deficiencias técnicas que presentan ambas figuras a la luz de su aplicación práctica, con especial detenimiento en el caso español.

\begin{abstract}
It is not surprising that criminals seek to cover up the proceeds of their illicit activities, so that they can freely enjoy them and, in doing so, sometimes use third parties; for this reason, the persecution of illegally originated assets has achieved an unprecedented prominence in the last decades. In line with what has been indicated, the present work intends, on the one hand, to analyze the figures of the confiscation of third-party assets in Spanish legislation following the recent reform of the Criminal Code, through LO 1/2015, dated March 30, as well as of the constitutional action of extinction of Colombian domain; and, on the other, to highlight the technical deficiencies presented by both figures in the light of their practical application, with special attention to the Spanish case.
\end{abstract}

\section{Palabras claves}

Decomiso, extinción de dominio, tercero, blanqueo de capitales, buena fe.

\section{Keywords}

Seizure, extinction of domain, third-party, money laundering, good faith.

\footnotetext{
* El presente artículo se deriva del trabajo de investigación que sobre el decomiso de bienes, presentó el autor como trabajo de investigación para optar por el título de máster en derecho penal económico en la Universidad Rey Juan Carlos de España en convenio con KPMG - Cátedra de Investigación Financiera. ** Máster en derecho penal económico, Universidad Rey Juan Carlos de España en convenio con KPMG - Cátedra de Investigación Financiera.
} 


\section{Introducción}

Para el derecho penal clásico la figura del decomiso tenía una importancia marginal; sin embargo, el cambio de paradigma de los delitos comunes a la delincuencia organizada trasnacional, ha modificado el modo en que las instituciones la confrontan (Restrepo, 2006, p. 5), lo cual ocurre mediante la tipificación de nuevos comportamientos delictivos, el incremento de las penas y, también, de la utilización y el afinamiento de las herramientas jurídicas ya existentes, pero de las cuales no se había hecho un uso relevante, como es el caso del decomiso.

En España, dentro del ordenamiento jurídico penal cohabitan dos modalidades de decomiso: una de carácter especial, aplicable a determinadas conductas delictivas taxativamente señaladas por la ley, $v$. gr., el tráfico de drogas y el blanqueo de capitales; $y$, la segunda, al amparo de una regulación genérica sobre decomiso recogida en ocho artículos distintos, introducidos tras la última reforma al Código Penal -en adelante, C. P.- en el año 2015. Esta última será el objeto del presente análisis, concretamente, el decomiso de bienes de tercero, previsto en el art. 127 quater C. P. Por su parte, en Colombia, la situación es similar: existe, por un lado, el comiso penal descrito en el art. 100 C. P. y la acción constitucional de extinción de dominio, regulada por la Ley 793 de 2002, a la cual se dedica este artículo.

En tal sentido, desde el derecho internacional se ha exhortado a los Estados tanto en el ámbito internacional como en el comunitario -en adelante, UE-, para que adopten los mecanismos necesarios que permitan recuperar los activos ilícitos, faciliten la persecución e incautación de los instrumentos y efectos del delito, al igual que de las ganancias ilícitas obtenidas con su realización; la ampliación del objeto del decomiso y la acción de extinción de dominio constituyen mecanismos idóneos para lograr dichos propósitos.

En efecto, en la normativa española, tras la última reforma operada mediante la Ley Orgánica (LO) 1 de 2015, se ha producido una verdadera transformación en materia de decomiso, como revela el desdoblamiento operado en el artículo 127 C. P., dando lugar a ocho normas distintas. En ellas, se amplía sustancialmente el régimen de algunas modalidades controvertidas, como el decomiso acordado sin condena, el de bienes de terceros o el ampliado, que ha dejado de ser una medida exclusivamente contra la criminalidad organizada y/o terrorista y ahora se extiende a otras actuaciones delictivas que reportan ingentes beneficios económicos (Roig, 2016, p. 2).

A su turno, Colombia, que históricamente ha sido un país insignia en producción e importación de drogas ilícitas en el plano mundial, requiere medidas más rigurosas que puedan responder eficazmente a la política criminal en la lucha contra la delincuencia organizada. Es por esto que una razón verdaderamente relevante para la aplicación de la extinción de dominio tiene que ver con idiosincrasia de los colombianos, exacerbada por una mentalidad cortoplacista para acumular fortuna. En tal sentido, es necesario traer a colación la frase según la cual "nuestros 
ciudadanos en su mayoría le temen más a la pérdida de los bienes y de la riqueza, que a la pérdida de la libertad" (Plazas, 2004, p. 18). Esa vergonzosa actitud, generalmente, parece ser producto de nuestra idiosincrasia tropical.

De ahí, que no exista un solo documento relacionado con la lucha contra la delincuencia organizada y otras formas graves de delincuencia que no haga mención al decomiso y a la acción de extinción de dominio como un medio de lucha eficaz contra los mismos, dado que las ganancias son consideradas el 'talón de Aquiles' de la delincuencia organizada (Aguado, 2013, p. 266). Por ello, es pertinente dar a estas figuras la importancia que merecen.

Dicho lo anterior, el objeto del presente trabajo consiste en realizar un análisis descriptivo sobre la nueva regulación del decomiso, con especial énfasis en el decomiso de bienes de tercero. Además, hacer un estudio comparativo sobre el decomiso de bienes de tercero en Colombia y España, para mostrar tanto las características más importantes de cada legislación como sus similitudes y diferencias.

\section{Legislación relativa al decomiso de bienes de tercero en España}

La nueva regulación del decomiso tras la reforma de la L.O de 30 de marzo de 2015, tiene su origen en la trasposición de la Directiva 2014/42/UE, sobre "Embargo y el decomiso de los instrumentos y del producto del delito en la Unión Europea", que extiende las disposiciones recogidas de la Decisión Marco 2001/500/ JAI, relativa al "Blanqueo de capitales, la identificación, seguimiento, embargo, incautación y decomiso de los instrumentos y productos del delito" y las de la Decisión Marco 2005/212/JAI relativa al "Decomiso de los productos, instrumentos y bienes relacionados con el delito", cuyas novedades afectan, concretamente, tres cuestiones: el decomiso ampliado, el decomiso sin sentencia y el decomiso de bienes de tercero.

No obstante, esta orientación político criminal contra la criminalidad organizada se inició a partir de la modificación al C. P. surtida por la Ley Orgánica 1 de 1988, de 24 de marzo, que, según se desprendía de su Exposición Motivos, estaba orientada a reducir y eliminar los beneficios económicos procedentes del delito, para lo cual se elevó la cuantía de la pena de multa, se amplió el alcance del decomiso y se tipificó como delito de receptación especial el blanqueo de dinero de origen delictivo (Fiscalía General del Estado, 2010, p. 12).

Con la última reforma al C. P., operada en el 2015, atendiendo las directrices de la Directiva 2014/42/UE, las disposiciones en materia de decomiso previstas en los artículos 127 y 128 C.P. se extendieron mucho, para dar lugar a ocho normas distintas: artículos 127 bis (decomiso ampliado), ter (decomiso sin sentencia condenatoria), quater (decomiso de bienes de terceros), quinquíes y sexíes (decomiso de una actividad delictiva continuada), septíes (ejecución efectiva del decomiso) y octies (otras disposiciones).

En lo atinente al decomiso de bienes de terceros, el Proyecto de Directiva, en su apartado $6^{\circ}$, se estableció que 
[1]os Estados miembros adoptarán las medidas necesarias para poder proceder al decomiso de: a) los productos transferidos a terceros por una persona condenada o en su nombre, o por los sospechosos o acusados que se hallen en las circunstancias del artículo 5, o b) de otros bienes de la persona condenada transferidos a terceros con objeto de evitar el decomiso de bienes cuyo valor corresponda a los productos. Se podrá proceder al decomiso de los productos o bienes contemplados en el apartado 1 cuando a) una evaluación, basada en hechos concretos relativos a la persona condenada, sospechosa o acusada, indique que es poco probable que el decomiso de bienes de la persona condenada, o del sospechoso o acusado que se halle en las circunstancias contempladas en el artículo 5, vaya a prosperar, y b) los productos o bienes se hubieran transferido de forma gratuita o a cambio de un importe inferior a su valor de mercado, si el tercero: i) tratándose de productos, conocía su origen ilícito o, de no conocerlo, una persona razonable en su misma situación habría sospechado que su origen era ilícito, basándose en hechos y circunstancias concretas; ii) tratándose de otros bienes, tenía conocimiento de que se habían transferido con objeto de evitar el decomiso de bienes cuyo valor correspondía con el de los productos o, de no tener dicho conocimiento, una persona razonable en su misma situación habría sospechado que se habían transferido para evitar el citado decomiso, basándose en hechos y circunstancias concretas.

El legislador español recogió dicha disposición en el art. 127 quater C. P., que, en su apartado primero, establece:

[1]os jueces y tribunales podrán acordar también el decomiso de los bienes, efectos y ganancias a que se refieren los artículos anteriores que hayan sido transferidos a terceras personas, o de un valor equivalente a los mismos, en los siguientes casos:

a) En el caso de los efectos y ganancias, cuando los hubieran adquirido con conocimiento de que proceden de una actividad ilícita o cuando una persona diligente habría tenido motivos para sospechar, en las circunstancias del caso, de su origen ilícito. b) En el caso de otros bienes, cuando los hubieran adquirido con conocimiento de que de este modo se dificultaba su decomiso o cuando una persona diligente habría tenido motivos para sospechar, en las circunstancias del caso, que de ese modo se dificultaba su decomiso.

2. Se presumirá, salvo prueba en contrario, que el tercero ha conocido o ha tenido motivos para sospechar que se trataba de bienes procedentes de una actividad ilícita o que eran transferidos para evitar su decomiso, cuando los bienes o efectos le hubieran sido transferidos a título gratuito o por un precio inferior al real de mercado.

Esta modalidad de decomiso presenta novedades importantes que deben mencionarse, pues permite acordar la medida sobre los bienes, efectos y ganancias transferidos a terceras personas en los siguientes supuestos: a) en el caso de los efectos y ganancias, cuando los hubieran adquirido con conocimiento de que proceden de una actividad ilícita $\mathrm{y}, \mathrm{b}$ ) tratándose de otros bienes, una persona diligente habría tenido motivos suficientes para sospechar, en las circunstancias del caso, de su origen ilícito o los hubieran adquirido a sabiendas de que esta era su finalidad. A continuación, se establece una presunción iuris tantum de trasmisión ilícita al tercero, cuando ella se realiza a título gratuito o por un precio vil.

La Comisión justificó esta nueva disposición, puesto que, con regularidad, cuando los delincuentes son investigados y sus propiedades perseguidas o, inclu- 
so, antes de que eso suceda, transfieren sus activos a terceras personas con el fin de evitar su decomiso y eludir cualquier acción judicial que pueda recaer sobre estos (Roma et al, 2015, p. 45). En tales supuestos, es necesario determinar cuál es la verdadera capacidad económica de esas personas, para valorar los hechos (Jaen y Perrino, 2015, p. 5) por lo cual, en determinados casos, es procedente aplicar la llamada teoría del 'levantamiento del velo societario', en orden a conocer, mediante prueba directa o indicios objetivamente fundados, si el patrimonio de una sociedad o de una persona pertenece, en realidad, a un 'hombre de atrás'.

Igualmente, se establece la posibilidad de acordar la medida por un valor equivalente, ante la imposibilidad de encontrar los bienes del investigado o condenado. Ello, cuando no sea posible localizarlos, hayan sido destruidos, su valor haya mermado con respecto a su adquisición o, por cualquier otra circunstancia, el juez o tribunal puedan, mediante la estimación y valoración de la actividad desarrollada, determinar una cantidad frente a cuyo importe quedará autorizado el decomiso de bienes (Mir, 2015, p. 385). Asimismo, aunque parece contemplarse la adquisición imprudente, en realidad exime de la prueba del dolo en la adquisición, puesto que, a veces, ello es difícil de acreditar (Roig, 2016, p. 66). De ahí, el fundamento de las presunciones iuris tantum recogidas en el apartado segundo.

Aunado a lo anterior, el nuevo artículo admite la posibilidad de decretar el decomiso de bienes transferidos a terceras personas cuando concurra alguna de las causales que se enumeran allí, a no ser que pertenezcan a un tercero de buena fe, no responsable del delito, siempre que los haya adquirido legalmente, quien es protegido dentro de los límites previstos por el artículo 122 C. P. respecto de la responsabilidad del partícipe a título lucrativo; dice así: "El que por título lucrativo hubiere participado de los efectos de un delito, está obligado a la restitución de la cosa o al resarcimiento del daño hasta la cuantía de su participación".

Por último, conviene subrayar que la reforma tiene en cuenta el hecho habitual de la transmisión a terceras personas de los bienes originados en actividades delictivas, que, pese a ser algo considerado por la regulación anterior, fue mejorado con el fin de incrementar la eficacia del instituto y lograr una mayor seguridad jurídica a la hora de su aplicación; por eso, señala "es el caso característico de los testaferros, que simplemente prestan su nombre en un contrato o negocio que, en realidad, es de otra persona, siendo habitual que sean familiares del 'hombre de atrás', al tener que ser de su absoluta confianza, pues al fin y al cabo ellos son los propietarios formales del capital social".

\section{Concepto armonizado de decomiso}

La legislación española no dispensa un concepto de decomiso, de ahí que se deba recurrir a las disposiciones recogidas en los ámbitos comunitario e internacional sobre la materia. Así, tras la nueva reforma, se prevé que

[t]oda pena que se imponga por un delito doloso llevará consigo la pérdida de los efectos que de él provengan y de los bienes, medios o instrumentos con que se haya 
preparado o ejecutado, así como de las ganancias provenientes del delito, cualesquiera que sean las transformaciones que hubieren podido experimentar (artículo 127.1 C. P.).

Por su parte, la Decisión Marco 2005/212/JAI, lo define como "toda pena o medida dictada por un tribunal a raíz de un proceso penal relativo a una o varias infracciones penales, que tenga como consecuencia la privación definitiva de algún bien" (artículo 2). La Convención de las Naciones Unidas Contra el Tráfico Ilícito de Estupefacientes y Psicotrópicos de 1988, a su turno, define el decomiso como "la privación con carácter definitivo de algún bien por decisión de un Tribunal o de otra autoridad competente" [artículo 1 apartado f)].

Así mismo, el Convenio $n^{\circ} .141$ del Consejo de Europa, abierto a la firma en Estrasburgo el 8 noviembre 1990, sobre blanqueo, seguimiento, embargo y decomiso del producto de los delitos señala que consiste en "la privación definitiva de un bien ordenada por un Tribunal en un procedimiento relativo a un delito o delitos" [artículo 1 apartado f)], al tiempo que la Directiva 2014/42/UE proclama sobre el mismo asunto que es "la privación definitiva de un bien por un órgano jurisdiccional en relación con una infracción penal" [artículo 2 apartado 4]. Similar definición se recoge en la Convención de las Naciones Unidas contra la Delincuencia Organizada Transnacional en el artículo 2, apartado g). Doctrinalmente, el decomiso es entendido como la aprehensión absoluta y definitiva de los efectos, instrumentos o ganancias que se encuentren mediata o inmediatamente relacionados con una conducta punible (Muñoz y García, 2010, p. 621; García-Pablos, 2005, p. 147; Cerezo, 2004, p. 5).

Dicho lo anterior, se puede observar que la definición dogmática de decomiso es un concepto unánime y armonizado entre las diferentes normativas sobre la materia, pues todos coinciden en que, para que se pueda hablar de una verdadera medida de decomiso, deben concurrir de forma cumulativa los siguientes presupuestos: a) la privación definitiva del bien, instrumentos o producto del delito con que se haya preparado o ejecutado, b) que la medida haya sido acordada por un órgano judicial competente y, c) que exista una relación de causalidad entre los bienes e instrumentos y el delito, es decir, deben hallarse en una relación de medio a fin.

\section{Regulación positiva del decomiso en Colombia}

Esta institución jurídica apareció desde los primeros códigos penales de la República en el año 1890; desde entonces, ha sido objeto de regulación en las distintas reformas penales, con progresivos y notables cambios tanto en lo sustancial, como en lo procesal, desde la normativa sobre el decomiso (Ley 19 de 1890), hasta la expedición del más reciente Código de Procedimiento Penal (Ley 906 de 2004) (Restrepo, 2006, p. 8).

El artículo 85 de la Ley 19 de 1890, establecía:

[1]as armas o utensilios con que se haya ejecutado el delito, y los efectos en que éste consista, o que formen el cuerpo de él, se aplicarán al Estado como multa, a no ser 
que la sentencia disponga que se destruyan o, que se devuelvan a un tercero o quien se hubieran robado o sustraído, o que sin culpa suya se haya usado de ellos para cometer el delito.

Como pude verse, esta primera regulación ya incluía los dos elementos clásicos del decomiso: los instrumentos y efectos del delito, pero su redacción no indicaba con nitidez su verdadera naturaleza jurídica, dado que estaba concebida como una multa. Además, se contempló la destrucción de bienes y se garantizó la protección de los terceros de buena fe, presupuestos que, actualmente, se mantienen incólumes.

Como ya se expuso, esta figura ha experimentado múltiples modificaciones mediante las sucesivas reformas a los Códigos Penal y de Procedimiento Penal. En relación con el primero, mediante las Leyes 95 de 1936, art. 59; Decreto-Ley 100 de 1980, art. 110; 2 de 1984, art. 37; y 599 de 2000, art. 100. Respecto del segundo, las reformas han tenido por causa las Leyes 94 de 1938, art. 316; Decreto 050 de 1987, art. 365; Decreto 2700 de 1991, art. 338; 81 de 1993, art. 43; Ley 600 de 2000; y 906 de 2004 , art. 84 a 91 en materia de comiso.

La Ley 599 de 2000, C. P. vigente, establece:

Artículo 100. Comiso. Los instrumentos y efectos con los que se haya cometido la conducta punible o que provengan de su ejecución, y que no tengan libre comercio, pasarán a poder de la Fiscalía General de la Nación o a la entidad que ésta designe, a menos que la ley disponga su destrucción.

Igual medida se aplicará en los delitos dolosos, cuando los bienes, que tengan libre comercio y pertenezcan al responsable penalmente, sean utilizados para la realización de la conducta punible, o provengan de su ejecución.

En las conductas culposas, los vehículos automotores, naves o aeronaves, cualquier unidad montada sobre ruedas y los demás objetos que tengan libre comercio, se someterán a los experticios técnicos y se entregarán provisionalmente al propietario, legítimo tenedor salvo que se haya solicitado y decretado su embargo y secuestro. En tal caso, no procederá la entrega, hasta tanto no se tome decisión definitiva respecto de ellos.

La entrega será definitiva cuando se garantice el pago de los perjuicios, se hayan embargado bienes del sindicado en cuantía suficiente para atender al pago de aquellos, o hayan transcurrido diez y ocho (18) meses desde la realización de la conducta, sin que se haya producido la afectación del bien.

El legislador colombiano intentó ajustar los presupuestos de aplicación del decomiso a las normas internacionales sobre la lucha contra la delincuencia organizada (Convención de las Naciones Unidas Contra el Tráfico Ilícito de Estupefacientes y Sustancias Sicotrópicas, suscrita en Viena el 20 de diciembre de 1998 - ratificada por Colombia mediante la Ley 67 de 1993), empero, esta figura presentaba enormes falencias, entre ellas: a) se le hizo depender de una sentencia condenatoria durante el proceso penal; b) el catálogo de delitos para los que se dispuso resultó ser lacónico; c) no se dispuso de mecanismos para perseguir a titulares de los bienes diferentes del sindicado; y, d) no se estableció la posibilidad de aplicar la medida sobre los bienes equivalentes (Garzón, 2003, p. 324). 
Todas estas falencias se quisieron superar con la Ley 333 de 1996, de 19 de diciembre "Por la cual se establecen las normas de extinción de dominio sobre los bienes adquiridos de forma ilícita". Durante su vigencia, los resultados fueron notables, sin embargo, estaba lejos de alcanzar el objetivo trazado, porque, como la norma anterior, dependía de la responsabilidad penal del sindicado, por lo cual cuando el agente resultaba exento de responsabilidad penal la consecuencia obligada era la obligación de devolverle los bienes incautados a aquél, pues no era posible deducir que los mismos tuvieran una procedencia ilícita. Este fue el motivo principal que condujo a la derogación de dicha normativa (Lara, 2004, p. 112).

Así nació la Ley 793 de 27 de diciembre de 2002, "por la cual se deroga la Ley 333 de 1996 y se establecen las reglas que gobiernan la extinción de dominio", normativa luego modificada por la ley 1708 de 2014 que rige en la actualidad. Dicho lo anterior, es necesario precisar que el Estado colombiano prescindió desde entonces de la figura del decomiso dadas sus evidentes falencias, y, en su caso, ha optado por aplicar de manera sistemática el instituto de la extinción de dominio como medio eficaz en la lucha contra el narcotráfico y la delincuencia organizada. En adelante se hará referencia de forma exclusiva a tal instituto.

De esta manera, Lara (2004, p. 112) señala que la nueva disposición sobre la materia cambió la historia de Colombia, pues envía un mensaje claro: el delito no es rentable. Sus resultados son muy dicientes porque en año y medio de vigencia logró 191 sentencias de extinción de dominio sobre más de 1000 bienes y propiedades (Lara, 2004, p. 112). Aunque los resultados son muy ilustrativos, la eficacia apreciada no solo radica en una apropiada regulación sino, también, en la adecuada gestión de la Fiscalía General de la Nación, la Dirección Nacional de Estupefacientes (hoy Sociedad de Activos Especiales SAE) y demás instituciones del Estado.

\section{Concepto de extinción de dominio}

La definición de extinción de dominio es preceptiva y se encuentra en su norma marco, según la cual "es la pérdida de este derecho a favor del Estado, sin contraprestación ni compensación de naturaleza alguna para su titular. Esta acción es autónoma en los términos de la presente ley" (art. 1, Ley 793 de 2002), por su parte, el Código de Extinción de Dominio establece:

[1]a extinción de dominio es una consecuencia patrimonial de actividades ilícitas o que deterioran gravemente la moral social, consistente en la declaración de titularidad a favor del Estado de los bienes a que se refiere esta ley, por sentencia, sin contraprestación ni compensación de naturaleza alguna para el afectado (art. 15, Ley 1708 de 2014).

Asimismo, la Corte Constitucional señala que

[1]a extinción del dominio es una institución autónoma, de estirpe constitucional, de carácter patrimonial, en cuya virtud, previo juicio independiente del penal, con previa observancia de todas las garantías procesales, se desvirtúa mediante sentencia, 
que quien aparece como dueño de bienes adquiridos en cualquiera de las circunstancias previstas por la norma lo sea en realidad, pues el origen de su adquisición, ilegítimo y espurio, en cuanto contrario al orden jurídico, o a la moral colectiva, excluye a la propiedad que se alegaba de la protección otorgada por el artículo 58 de la Carta Política (Sentencia C-374 de 1997).

\section{Naturaleza jurídica del decomiso en ambas legislaciones}

Como ya se expresó, en España el mecanismo estatal frente a la delincuencia organizada con motivación económica es el decomiso; mientras que en Colombia se acude a la acción de extinción de domino. No obstante, en lo sucesivo se hace referencia siempre a la acción de decomiso para homogeneizar o, si se quiere, para hablar un mismo lenguaje.

La Corte Constitucional colombiana señala, en reiterados pronunciamientos (Sentencias C-374, 1997 y C- 409, 1993), que la acción de extinción de dominio es una institución jurídica concebida con un formidable rigor jurídico que la convierte en una herramienta tan novedosa como eficaz, caracterizada por ser una acción constitucional, pública, jurisdiccional, autónoma y expresamente regulada por el constituyente y relacionada con el régimen constitucional del derecho a la propiedad.

Es una acción constitucional, porque ha sido consagrada por el poder constituyente originario como el primer nivel de nuestro sistema democrático; además, fue concebida al nivel de otras acciones constitucionales $-v . g r$., las acciones de tutela, de grupo, de cumplimiento o las populares-, con las cuales se busca proteger los derechos individuales o colectivos más importantes de la sociedad, de tal forma que "con el precepto constitucional se buscó dotar al Estado de un instrumento eficaz para desestimular el delito, en especial ciertas expresiones de él" (Ospino, 2004, p. 64).

Es una acción pública, en cuanto el Estado colombiano salvaguarda solo el dominio de los bienes adquiridos de forma lícita, de tal suerte que será extinguido el dominio de aquellos títulos ilegítimos, al hilo de lo cual se protegen intereses superiores del Estado como el patrimonio público, el tesoro público y la moral social (Ospino, 2004, p. 64). Es jurisdiccional, puesto que a través de su ejercicio se desvirtúa la legitimidad del título sobre los bienes y ese es un típico acto jurisdiccional del Estado; además, su ejecución debe ceñirse a las garantías constitucionales y solo procede mediante la decisión de un juez (Corte Constitucional, sentencia C-374, 1997).

Es autónoma, dado que es independiente de los procesos penal y civil; en el primer caso, es independiente de la responsabilidad del afectado y, en el segundo supuesto, no está motivada por intereses patrimoniales, sino por intereses superiores del Estado. También, es directa, en tanto su procedencia está sujeta, únicamente, a la demostración de alguno de los supuestos señalados en la norma: enriquecimiento ilícito, perjuicio del tesoro público o grave deterioro a la moral social, entre otros (Ospino, 2004, p. 65). 
De igual forma, es una acción real, dado que establece la posibilidad de perseguir el bien al margen de la persona que ostente su titularidad o, lo que es lo mismo, la extinción del dominio es patrimonial y no constituye una consecuencia penal sino económica de los actos imputables a una persona; por lo tanto, no exige el dolo para su aplicación. Es complementaria, porque no excluye la aplicación del decomiso, la incautación, la ocupación y las demás medidas que se adopten dentro del proceso penal, en relación con los bienes que hayan servido como instrumento del delito o fruto del mismo. Por último, es una acción imprescriptible, porque puede ejercitarse en cualquier momento sin que en relación con ella opere término de prescripción alguno (Garzón, 2003, pp. 332-335).

Con base en lo anterior, como la acción de extinción de dominio no se erige sobre los postulados del derecho civil ni penal, debe decirse que ella es una figura de carácter especial.

Para un observador desprevenido, o, incluso, para el legislador de otras latitudes, la regulación de la acción en comento puede resultar, cuando menos, excesiva, pues se trata de una especie de 'engendro jurídico', erigido con el fin de combatir y eliminar cualquier ventaja patrimonial que provenga del delito. Pero lo cierto es que no podía ser de otra manera, atendida la política criminal del Estado en la lucha contra la delincuencia organizada trasnacional; Colombia, no se olvide, ha vivido durante varias décadas el flagelo del narcotráfico y los carteles de la droga, situación que ha compelido al Estado a responder de una forma distinta para enfrentar estas nuevas modalidades delictivas. Todo ello, porque la delincuencia con fines económicos es receptiva a las penas privativas de la libertad y resulta sancionada en mayor grado cuando es despojada del beneficio patrimonial, de sus bienes.

Dicho lo anterior, no hay nada que objetarle a esta acción constitucional denominada "Acción de extinción de dominio", en tanto herramienta eficaz en la lucha contra el crimen organizado y la delincuencia económica y por razones de interés general. El Estado no puede mostrarse complaciente con ninguna forma de enriquecimiento injusto, contrario a la ley, a la moral social, o al tesoro público.

En España, la discusión sobre la naturaleza jurídica del decomiso adquiere otro matiz, pues se trata de una institución jurídica incluida entre las denominadas 'consecuencias accesorias' y que, atendido su carácter heterogéneo, no se ha logrado un consenso entre los autores respecto de su naturaleza jurídica. El desacuerdo se fundamenta en tres posiciones distintas: un primer grupo, señala que se trata de una medida civil; el segundo, sostiene que consiste en una nueva reacción jurídica; $\mathrm{y}$, para terminar, el tercero, señala que es una consecuencia accesoria de carácter eminentemente penal.

Los primeros, es decir, quienes piensan que el decomiso es una medida civil o administrativa (Gracia, Boldovar y Alastuey, 2004, pp. 469-471), sostienen que -aunque la medida implique la privación o limitación de derechos, la competencia esté asignada al juez penal, se encuentre incorporada al C. P. y se decrete en un 
proceso penal-, no deja de ser una reacción jurídica de carácter civil. Además, porque se fundamenta en una situación patrimonial ilícita.

Por su parte, Octavio de Toledo y Ubieto (2002, p. 4), considera que el decomiso de efectos e instrumentos es una medida penal, porque se funda en la peligrosidad y cumple una función preventiva, en tanto impide que los mismos puedan ser utilizados en futuras actividades delictivas; sin embargo, el decomiso de las ganancias es de naturaleza civil, semejante a la responsabilidad civil ex delicto. Adicionalmente, se trata de una figura próxima a la responsabilidad civil dado que su gravedad reside en las ganancias (Mapelli, 1998, p. 50). Así mismo, Blanco (2007, pp. 64-65), para quien el decomiso de ganancias además de corregir una situación patrimonial ilícita, cumple también una función preventiva, porque envía un mensaje disuasorio en el sentido de que el delito no es una actividad rentable. Argumento que comparten López y García (1996, p. 81).

El segundo segmento de autores estima que el decomiso es una nueva reacción jurídica. Así, Mir (2015, p. 831), señala que el decomiso no está previsto como una amenaza destinada a disuadir la comisión de un delito ni como castigo merecido por lo cual tampoco responde a ninguno de los fines de la pena: ni a la prevención a través de la motivación ni a la retribución, ni obedece a la necesidad de tratar la peligrosidad del sujeto como las medidas de seguridad. Se trata, en realidad, de una consecuencia accesoria de naturaleza peculiar.

Choclán (2001, p. 28), a su vez, expresa, lo siguiente: en primer lugar, que pese a ser una medida acordada en un proceso penal por la comisión de un delito, no cumple igual propósito que la pena, pues no constituye una reacción frente al delito ni la peligrosidad del autor; segundo, que no se trata de una medida de seguridad porque no recae en forma directa sobre el delincuente; $y$, tercero, que tampoco es una medida propiamente civil pese a que el dinero producto de la venta de los bienes de lícito comercio es destinado a cubrir la responsabilidad civil derivada del delito. De lo anterior, se puede inferir que para ese autor es una nueva reacción jurídica.

Con similar argumento se expresan Ríos (2011, p. 218) y Cerezo (2004, pp. 2436). Para este último, el decomiso no puede considerarse una medida civil dado que no está concebida como un medio para restablecer derechos de índole patrimonial como, por ejemplo, la indemnización. No obstante, esa es una apreciación que debe entenderse en un sentido literal porque el decomiso cumple eventualmente una función de reparación o indemnización, toda vez que el dinero producto de la venta de bienes o instrumento decomisados (de lícito comercio) es destinado a cubrir la responsabilidad civil derivada del delito cuando los bienes lícitos del penalmente responsable no sean insuficientes para tal fin, aunque sea una función residual. Aunque puede existir responsabilidad civil sin que haya responsabilidad penal, eso no aplica para el decomiso que está sujeto al principio acusatorio.

Al hilo de este razonamiento, debe decirse que dicha interpretación ha sido admitida por el Tribunal Supremo en diversos pronunciamientos (Sentencias 600, 
2012; 5571, 2012; 11, 2011; 353, 2011; 16, 2009 y 130, 2009), el cual consideró el decomiso como una 'consecuencia accesoria', al margen de las penas como de las medidas de seguridad y entiende que su "naturaleza es, según la doctrina más autorizada, la de una tercera clase de sanciones penales, siguiendo así el Código Penal la línea iniciada por los derechos penales germánicos (CP Suizo o CP Alemán) de establecer un tercer genero de sanciones bajo la denominación de "consecuencias accesorias".

Por último, para quienes se trata de una consecuencia accesoria de carácter penal, como García-Pablos (2005, p. 147), el decomiso hace parte del catálogo de instrumentos represivos del Estado regulados por el C. P., motivado por la comisión de un delito y de competencia asignada a los tribunales de lo criminal, por lo tanto su naturaleza es penal; además, para él no tiene sentido que la medida se imponga por la presunta comisión de un delito, se resuelva en un proceso penal sometido a la competencia de un juez penal y que su naturaleza corresponda a una rama distinta del ordenamiento jurídico. Gascón (2007), por su parte, entiende que el decomiso hace parte del derecho sancionador y agrega que es irrelevante, para clasificar su naturaleza jurídica, su carácter administrativo, civil o judicial (p. 83), porque los jueces penales pueden imponer sanciones penales y no penales como, por ejemplo, en materia de responsabilidad civil. Sirve también como medio de prevención general, dado que el decomiso puede afectar con más dureza que la propia pena (Jescheck y Weigend, 2003, p. 724). Con similares argumentos se expresan Ayo (1997, p. 271); Aguado (2000, p. 41); Luzón (2004, p. 57); Bacigalupo y Bajo (2010, p. 195) y Díez (2015, p. 801).

Así lo señala el TEDH (1995), cuando establece que es de indudable naturaleza penal, en la medida en que se impone como consecuencia de la realización de un hecho típico y antijurídico, mediante acusación penal y durante un procedimiento penal. Aunado a ello, se trata de una consecuencia jurídica análoga a la medida de seguridad, orientada principalmente a impedir que el bien o la cosa puedan favorecer futuros hechos delictivos tal y como sucede con la medida de seguridad, por ende el decomiso está sujeto a las restricciones del principio acusatorio y proporcionalidad.

En vista de las variadas interpretaciones respecto de la naturaleza jurídica del decomiso, es atinada la postura de la doctrina mayoritaria que alude a su naturaleza penal: primero, porque el decomiso de bienes, efectos o instrumentos del delito, se basa en el principio acusatorio, es decir, solo procede ante una acusación formal fundada en una prueba directa $\mathrm{o}$, al menos, indicios objetivamente fundados que indican la presunta comisión de un delito; segundo, en tanto se valora la gravedad del perjuicio irrogado con la conducta delictiva del cual proviene; tercero, pues se impone durante el proceso penal bajo la competencia de un juez penal.

\section{La presunción de inocencia y la carga de la prueba}

La nueva redacción del art. 127 quater C. P. tras la reforma de 2015, ha suscitado una gran controversia porque para algunos autores supone una amenaza para la 
presunción de inocencia y, además, traslada la carga de la prueba al tercero. En ese sentido, Hava (2015, p. 222) sostiene que con la entrada en vigor de la nueva reforma los terceros de buena fe quedan en una posición más que delicada con respecto a la adquisición de cualquier tipo de bienes, porque pueden ser decomisados si son ilícitos o aquellos que los sustituyan, conforme a las reglas del decomiso por valor equivalente, debiendo adoptar en todo momento una actitud suspicaz (esto es más cuidadosa que una persona media) y, además, transfiere al tercero la carga probatoria (teoría diabólica). Esa autora, agrega que su contenido equivale a hacer penalmente responsable a una persona por el mero hecho de comportarse de modo levemente imprudente, porque a estas alturas es difícil mantener que el decomiso no es una pena al menos en el sentido aflictivo del término.

De modo semejante, Aguado (2014, p. 49) sostiene que, mediante esta ambiciosa y prometedora reforma, se pretende -según lo señalado en la Exposición de Motivos de la Propuesta-introducir algunas mejoras técnicas orientadas a incrementar la eficacia y la seguridad jurídica en su aplicación. No obstante, de lo que no cabe duda tras la lectura del artículo comentado es que para el legislador español el fin justifica los medios, por lo cual prevalece la eficacia por encima de los derechos fundamentales y las garantías constitucionales, y se comprometen la presunción de inocencia y el principio de proporcionalidad. Con argumentos parecidos, se expresan Corcoy (2015, p. 451) y Cuello y Mapelli (2015, p. 376).

A la vista de lo señalado por los autores, hay varios aspectos a considerar: primero, no es compartible su razonamiento si se tiene en cuenta que no puede haber vulneración al derecho a la presunción de inocencia, cuando se impone un deber de diligencia mínimo al tercero adquirente en sus transacciones -es la cuestión donde estriba su planteamiento- si se consideran las siguientes razones: en primer lugar, porque el derecho penal, a diferencia de otras ramas del ordenamiento jurídico, no se conforma con la verdad formal con arreglo a determinados patrones sino que busca la verdad material y derivar la forma real de participación (Prats y Morán, 2001, p. 618).

En segundo lugar, la figura jurídica examinada consiste en una medida que se dirige ad personam, asociada con la responsabilidad del autor en un hecho delictivo, y no solo in rem lo que, según el autor, tiene trascendencia en cuanto a las reglas de la prueba y a la posibilidad de acordar la medida contra el tercero no responsable penalmente por el hecho. Significa, entonces, que el decomiso por su carácter eminentemente punitivo se rige por los principios jurídico-constitucionales que vinculan al derecho penal (Choclán, 2001, p. 30). De manera que la investigación del patrimonio criminal y el decomiso se edifican sobre el principio acusatorio (Tribunal Supremo, sentencias 969 de 2013 y 1008 de 2014; Fiscalía General del Estado, 2010) y, por consiguiente, para que exista una acusación, deben existir pruebas directas $\mathrm{o}$, al menos, indicios objetivamente fundados que permitan inferir la presunta comisión de un delito (Tribunal Constitucional, sentencia 135, 2003 y Tribunal Supremo, sentencia 852, 2013); así, pues, las presunciones que contiene el citado artículo (127 quater), bajo ninguna circunstancia lesionan el principio consti- 
tucional a la presunción de inocencia, teniendo en cuenta que la prueba indiciaria ha sido aceptada por la doctrina constitucional como un medio idóneo para enervar dicha presunción.

En tercer lugar, porque el decomiso es una institución jurídica que no está orientada a proteger derechos individuales sino derechos colectivos, de interés general o, también llamado el 'orden socioeconómico', y su finalidad no es otra que la de impedir que el delito pueda generar el más mínimo beneficio económico para sus autores y, de esta forma, se produzca un enriquecimiento ilícito. Además, a través de la investigación de los flujos o movimientos patrimoniales puede constatarse el iter criminis de determinados tipos penales (Fiscalía General del Estado, 2010, p. 8).

En Colombia, la cuestión acerca de la presunción de inocencia tiene un tratamiento distinto que obedece a la propia naturaleza de la acción de extinción de dominio. En materia de derecho penal, los principios que informan el proceso respectivo, como el in dubio pro reo, la presunción de inocencia, el derecho de defensa, el principio de favorabilidad, el debido proceso penal, entre otros, no son extrapolables a la extinción de dominio. Es posible que, para un observador desprevenido, la aplicación de la medida en comento vulnere la presunción de inocencia por cuanto no existe una sentencia condenatoria donde se acredite el origen ilegítimo de los bienes, a la luz de lo cual sería cuestionable que se produjera el despojo sin haberse establecido judicialmente su ilicitud. En ese sentido, la Corte Constitucional señala:

[e]sta acción no se trata, de manera alguna, de una institución que haga parte del ejercicio punitivo del estado y por ello no le son trasladables las garantías constitucionales referidas al delito, al proceso penal y a la pena. Por lo tanto, en el ámbito de la acción de extinción de dominio no puede hablarse de presunción de inocencia y, en consecuencia, de la prohibición de la inversión de la carga de la prueba, pues estas garantías resultan contrarias a la índole constitucional de la acción (Corte Constitucional, sentencias C- 460, 1992 y C- 409, 1997).

En igual sentido, Ospino (2004, p. 65), señala que solo se puede hablar de presunción de inocencia en un proceso penal o en un proceso disciplinario sancionatorio u otra medida, donde se tenga a una persona como sujeto pasivo de la acción, pero en un proceso donde la acción recae sobre cosas, es decir, sobre bienes, no es posible hablar de presunción de inocencia, pues no se tiene la posibilidad de enfrentar a una persona directamente; tampoco se exige culpabilidad ni la responsabilidad de la persona, en consecuencia no existe una persona a quien presumir inocente ello no es predicable de los bienes.

A su turno, la Corte Constitucional y la Corte Suprema señalan que no se requiere de una sentencia condenatoria para que proceda la acción en comento, ni siquiera es indispensable haber iniciado la acción penal por el delito de enriquecimiento ilícito, lo que resulta entendible de cara al trámite de extinción de dominio por lo cual es improcedente hablar de una conculcación al principio de la presunción de inocencia (Corte Constitucional, sentencia C-319, 1996, Corte Suprema de Justicia, auto radicado 10467, 1996). 
Con respecto a la carga de la prueba, el tratamiento es evidentemente opuesto al caso español: en Colombia no hay inversión de la carga de la prueba porque, como ya se dijo, la naturaleza jurídica de la acción comentada no responde a los principios que informan el derecho penal, como si sucede en España. En el caso colombiano, por tratarse de una figura especial, autónoma e independiente, el legislador prescinde de todas esas exigencias técnicas que no hacen más que dificultar la persecución del patrimonio criminal. Pero esta cuestión no es un asunto menor $\mathrm{y}$, por ello, uno de los aspectos de mayor interés para la normativa internacional es el relativo al tratamiento de la carga de la prueba en materia de decomiso de bienes. Al respecto, la Convención de las Naciones Unidas Contra la Delincuencia Organizada Trasnacional recomienda:

Art. 7. Los Estados parte podrán considerar la posibilidad de exigir a un delincuente que demuestre el origen lícito del presunto producto del delito o de otros bienes expuestos a decomiso, en la medida en que ello sea conforme con los principios de su derecho interno y con la índole del proceso judicial u otras actuaciones conexas.

Colombia, tras adaptar dicha Convención al derecho interno, hizo una reserva en el numeral 7 del artículo citado, que establece la inversión de la carga de la prueba ["demuestre el origen lícito del presunto producto del delito o de otros bienes expuestos a decomiso"]. Por esto, la Corte Constitucional (Sentencia C- 176, 1994), consideró que la inversión de la carga de la prueba en materia penal, relativa al comiso, es contraria al artículo 29 de la Constitución colombiana (debido proceso), al artículo 14, numeral 2 del Pacto Internacional de derechos Civiles y Políticos de las Naciones Unidas y el artículo, numeral 2 de la Convención Americana de los Derechos Humanos. En ese sentido, la Corte Constitucional señaló:

El sistema penal y procesal colombiano se encuentra edificado sobre sobre el principio de la presunción de inocencia consagrado en el artículo 29 de la Constitución, que proclama: "toda persona se presume inocente mientras no se le haya declarado judicialmente culpable". De modo que, la carga de la prueba está a cargo del Estado, sin perjuicio de que los sujetos procesales también puedan ejercer por iniciativa probatoria propia a fin de buscar el esclarecimiento de los hechos objeto de debate (Sentencia C- 176, 1994).

No obstante, entre los objetivos de la Ley de Extinción de Dominio (Ley 793 de 2002), la recopilación del acervo probatorio corresponde al ente instructor, con el fin de que se pueda develar de forma cierta la presunta responsabilidad penal o, al menos, se pueda inferir más allá de toda duda razonable, que los bienes fueron adquiridos con recursos provenientes de actividades ilícitas. Es decir, el debate probatorio debe girar en torno a establecer la procedencia de los fondos utilizados en la adquisición y no en determinar la responsabilidad penal de su titular que es, sin lugar a dudas, el sentido teleológico de la ley aludida.

Es por esto que en materia de extinción de dominio no se puede entender que exista inversión de la carga de la prueba ni que, por lo tanto, se han desconocido derechos constitucionales por cuanto se acude a la teoría de la carga dinámica de la prueba. Si bien la presunción de inocencia no es aplicable en el ámbito de la extin- 
ción de dominio, en esta tampoco hay lugar a presumir la procedencia ilícita de los bienes que son objeto de ella, pues al Estado le corresponde demostrar a través de las entidades competentes el origen ilícito (Corte Constitucional, sentencia C- 319, 1996). Así, la Corte Constitucional señaló:

[n]o obstante, este derecho de oposición a la procedencia de la declaratoria de extinción implica un comportamiento dinámico del afectado, pues es claro que no puede oponerse con sus solas manifestaciones. Es decir, las negaciones indefinidas, en el sentido de que no es ilícita la procedencia de los bienes, no lo eximen del deber de aportar los elementos de convicción que desvirtúan la inferencia, probatoriamente fundada, del Estado en cuanto a esa ilícita procedencia. De ahí, que el afectado con el ejercicio de la acción de extinción de dominio, le sea aplicable la teoría de la carga dinámica de la prueba, que consiste en que debe probar un hecho quien esté en mejores condiciones de hacerlo, es decir, le corresponde aportar las pruebas al proceso. Así, en el caso de la acción de extinción de dominio, el titular del dominio sobre los bienes, es quien está en mejores condiciones de probar su origen lícito, es él quien debe aportar las pruebas que acrediten ese hecho y que se desvirtúen el alcance de las pruebas practicadas por el Estado en relación con la ilícita procedencia de esos bienes (Sentencia C- 319, 1996).

En sentido similar, el Consejo de Estado sostiene que "el derecho de oposición a la procedencia de la declaratoria de extinción implica un comportamiento dinámico del afectado, pues es claro que no puede oponerse con sus solas manifestaciones" (Sección Tercera, 2001 y 2002). De donde resulta que al afectado con el ejercicio de la acción de extinción de dominio le sea aplicable la teoría de la carga dinámica de la prueba, que consiste en que debe probar un hecho quien esté en mejores condiciones para hacerlo.

Además, debe tenerse en cuenta que una vez ejercitada la acción extintiva de dominio los afectados son quienes están llamados a ejercitar la defensa de sus intereses si se demuestra que sus bienes fueron adquiridos con dineros de procedencia lícita; igualmente, dado que la obtención de la prueba supone un grado de dificultad alto, se admite el indicio como medio de prueba para enervar la presunción de licitud de los bienes (Lara, 2004, p. 108). Así las cosas, entonces, cabe preguntar, ¿por qué no invertir la carga de la prueba únicamente sobre determinados delitos? Eso, en tiempos remotos, suponía una amenaza para las garantías constitucionales sobre la base de la debilidad del procesado frente al omnipotente Estado; sin embargo, hoy en día, con el nuevo paradigma de la delincuencia organizada, la ecuación ha variado de manera sustancial dado que las grandes organizaciones criminales de alto rendimiento económico son, en muchas ocasiones, más poderosas e influyentes que los mismos Estados, incluso en ocasiones estas organizaciones llegan a someterlos. No se trata, entonces, del indefenso procesado (Ospino, 2004, p. 74), pues el Estado se enfrenta a estructuras de poder que pueden llegar a superarlo.

El mismo autor para explicar mejor la cuestión señala que la dinámica con la cual funciona esta acción es equiparable al proceso penal: ante la existencia de los presupuestos necesarios para abrir un proceso penal, se procede a la vinculación 
y captura del implicado; en este caso ocurre algo similar, pues, si se acuerda la extinción es porque existe la convicción suficiente para arribar a una sentencia de extinción de dominio sin que ello suponga, necesariamente, la inversión de la carga de la prueba.

Para finalizar se debe tener en cuenta que en materia probatoria se admite como medio de prueba para ejercitar la acción de extinción de dominio el 'hecho notorio', con base en el cual se puede inferir a partir de las probanzas arrimadas a la actuación que se dedica profesionalmente a una actividad ilícita. No será necesario, entonces, entrar a pormenorizar cuál o cuáles bienes fueron adquiridos con determinada actividad o hechos precisos en cuanto a las fechas y momentos, porque ello sería imposible; a tales efectos, basta con que se tenga la convicción de aquella dedicación profesional y esto es lo que ocurriría con el ex narcotraficante Pablo Emilio Escobar Gaviria (Pinilla, 1998).

\section{La buena fe exenta de culpa}

$\mathrm{Al}$ tenor de lo dispuesto en el art. 127 quater C. P., el decomiso también puede recaer sobre los bienes cuya propiedad es distinta a la de quien ha participado en la infracción penal; además, puede alcanzar a terceros en los supuestos en que la ley considera que la adquisición no debe ser protegida, teniendo en cuenta que esto último ocurre en los siguientes supuestos: 1) que los bienes pertenezcan a un tercero; 2) que su adquisición hubiera sido de buena fe; 3) que la adquisición se haya realizado legalmente; $y, 4$ ) que el titular de los bienes no sea responsable del delito.

Se considera que la adquisición del bien por parte del tercero ha sido de mala fe, conforme a lo dispuesto en el mismo precepto, cuando: 1) en el caso de efectos y ganancias, no exista duda sobre su origen ilícito, teniendo el adquiriente el deber legal de sospechar conforme a las circunstancias, de su condición; y, 2) tratándose de otros bienes, la adquisición se realiza con el propósito de evitar su decomiso o, una persona diligente habría tenido motivos para sospechar que así ocurría. A renglón seguido, señala que serán objeto de la medida aquellos bienes transferidos a título gratuito o por un precio vil.

La buena fe ha sido desde tiempos inmemoriales uno de los principios fundamentales del derecho, ya sea en su aspecto activo como el deber de proceder con lealtad en nuestras relaciones jurídicas, o en su vertiente positiva como el derecho a esperar que los demás procedan de la misma forma (Corte Constitucional, sentencia C- 540, 1995). Lo esencial es que la buena fe es un principio general del derecho y no una regla de derecho (De Almeda, 2004, p. 35). Un principio general del derecho es un criterio o valor no legislado, ni consuetudinario, que permite dentro del sistema jurídico llenar las lagunas de la ley:

[...] una respuesta no positiva del problema, por virtud de la cual sea necesario acudir en ocasiones a criterios no legislados y no consuetudinarios. Aparece entonces la necesidad de decidir o resolver con arreglo a los criterios extralegales, lo cual no 
quiere decir ni mucho menos que estos criterios (extralegales), deban considerarse como extrajurídicos (Diez-Picazo, 1988, p. 152).

La buena fe para Choclán (2001, p. 55) consiste en la ignorancia de las circunstancias que permiten el decomiso, mientras que para Ayo (1997, p. 274) es el desconocimiento del origen delictivo del bien; por su parte, Martín (2005, p. 233) sostiene que habrá mala fe cuando el adquirente tenga conocimiento del origen ilícito de la cosa, o de su condición de decomisable, incluso cuando no tenga origen ilícito o se halle ante la posibilidad de que así sea. Este último autor, a diferencia de los otros, se refiere a un conocimiento absoluto sobre el origen ilícito del bien, cuando decide emplear la frase 'tenga conocimiento' con exclusión de la mera sospecha o el total desconocimiento de cualquier vicio que invalide la adquisición.

En Colombia, la ley mediante la cual se regula la acción de extinción de dominio establece que "[1]o dispuesto en el presente artículo no podría interpretarse en perjuicio de los derechos de terceros de buena fe exentos de culpa" (artículo 3). Dicha protección otorgada a los terceros de buena fe exentos de culpa, resulta compatible con la Constitución (Corte Constitucional, sentencia C- 1007, 2002).

Dicho lo anterior, entonces, cabe preguntar, ¿cuándo se considera que la adquisición es de buena fe y debe ser protegida por la ley? Para responder a este interrogante se debe acudir a lo señalado por la Sala de Extinción de dominio, del Tribunal Superior de Bogotá:

La categoría conceptual de la buena fe exenta de culpa, se hace ante el cumplimiento de los actos jurídicos y de las obligaciones en general, que deben ser ejecutados de buena fe, es decir, con lealtad, con la intención positiva de realizar la finalidad social y jurídica a que obedece. Es que, no sólo se exige la honestidad en el propósito, sino además, la prudencia, diligencia y cuidado; principios constitutivos de la culpa en materia civil, que es el instituto al cual se refiere la normatividad cuando exige que el tercero esté exento de culpa; por tanto, como en este evento no se exonera la culpa, resulta inadmisible como lo sugiere la recurrente, proteger un derecho que no se reconoce con procedencia lícita (Sentencia del 8 de febrero de 2012).

La ley distingue tres clases de culpa: culpa grave o negligencia grave, culpa leve o descuido leve y culpa o descuido levísimo. Ambas legislaciones coinciden sobre el criterio de la buena fe en los negocios, no solo como un deber de lealtad y honestidad en las transacciones sino que, además, debe haber cierto grado de diligencia y cuidado en estas, para que pueda ser considerado como un verdadero tercero de buena fe y gozar de la protección del derecho a la propiedad.

Para ser tercero de buena fe también se exige que la transferencia se haya realizado legalmente. La jurisprudencia fijó como un requisito inexorable para evitar la medida de decomiso "que el tercero haya adquirido los bienes de forma legal". Consideramos que esta previsión es un tanto inocua, teniendo en cuenta que los delincuentes transfieren sus bienes o activos a terceros procurando eliminar cualquier rastro de ilicitud y, en efecto, evitar que estos sean decomisados, pues el propósito de la operación no es otro que darle apariencia de legalidad a la trans- 
ferencia de titularidad y ampararse bajo la protección lege lata sobre el derecho de propiedad que se otorga al titular formal.

Dicho esto, se debe formular el siguiente interrogante: ¿cómo una transferencia de titularidad de bienes puede pretender parecer legítima sin que se haya realizado, al menos, legalmente? La respuesta salta a la vista: sería un verdadero despropósito hacerlo de forma opuesta a la norma, pues la transferencia siempre se hará legalmente -cuando menos sobre el papel- por lo que será necesario mirar más allá de la mera formalidad.

Asimismo, establece el TS que el "tercero no haya participado en el delito" (sentencias 1778 de 2013 y R.A. 38791 de 2014) lo cual genera bastante asombro, teniendo en cuenta que si ha participado en la actividad criminal, sencillamente, no tiene la condición de tercero y, en su caso, será penalmente responsable a título de autor o partícipe del delito fuente y procede el decomiso directo, ampliado o por un valor equivalente, según sea el caso. Además, la medida de decomiso en el proceso penal no está vinculada a la pertenencia del bien al responsable criminal, sino, únicamente, a la demostración del origen ilícito del producto, ganancias o de su utilización para fines criminales, por lo que, en principio, siendo absuelto o perteneciendo el bien a un tercero, podrá acordarse el decomiso sobre los efectos del delito, desvirtuando la presunción de buena fe de los arts. 433 y 434 de la LH y acreditar que era un tercero aparente para encubrir su origen ilícito.

\section{Responsabilidad penal del tercero de mala fe}

En España, la responsabilidad penal del tercero de mala fe está limitada a un único tipo penal, es decir, al delito de blanqueo de capitales. El decomiso, como consecuencia accesoria del delito, no exige la concurrencia de elementos objetivos ni subjetivos, es decir, que el titular haya participado en la actividad criminal, pues basta que se acredite haber contribuido -al menos de modo imprudente- a dificultar el decomiso del bien, sin perjuicio de que dicho comportamiento pueda ser constitutivo, dadas las circunstancias, de un delito de receptación o de blanqueo de capitales (Choclán, 2001, p. 56). Estas determinadas circunstancias podrán acreditarse mediante prueba indiciaria, construida con elementos como las relaciones preexistentes entre el transmitente y el adquirente, la adecuación del precio al valor del bien, la efectividad del pago o la procedencia del dinero utilizado para este último, entre otros aspectos (Fiscalía General del Estado, 2010, p. 25).

Tras la nueva redacción del art. 127 quater C. P., es compartible el razonamiento de Campos (2013), cuando señala que, primero, el citado precepto, se refiere a que el adquirente conozca o sospeche que proceden de una actividad delictiva. Cabe recordar que el art. 301 C. P., como primera forma comisiva del blanqueo de capitales, se refiere "al que adquiera, posea, utilice, convierta, o transmita bienes, sabiendo que éstos tienen su origen en una actividad delictiva, cometida por él o por cualquier tercera persona". En el caso recogido en el artículo 127 quater C. P., lo que debería determinarse es el enjuiciamiento del tercero que realiza tal conducta como autor responsable de un delito de blanqueo de capitales, por dolo directo, si 
conocía la procedencia ilícita o, bien, por dolo eventual, si tan solo lo sospechaba dadas las circunstancias del caso.

Añade que, en el segundo de los supuestos contemplados por el precepto para autorizar el decomiso de bienes de terceros, se refiere a que se adquieran los bienes con conocimiento o sospecha que de este modo se dificultaba su decomiso. Procede transcribir la parte del art. 301 C. P., cuando se refiere al autor del blanqueo de capitales diciendo es quien "realice cualquier otro acto para ocultar o encubrir su origen ilícito, o para ayudar a la persona que haya participado en la infracción o infracciones a eludir las consecuencias legales de sus actos". El que participa activamente auxiliando al responsable de un delito a eludir el decomiso, completa todos los elementos del delito de blanqueo de capitales.

Por último, la aclaración contenida en el apartado 2 del 127 quater C. P., referida a los supuestos de adquisición a título gratuito o por precio inferior al de mercado, son simplemente elementos fácticos que permiten deducir el elemento subjetivo del delito de blanqueo de capitales (Campos, 2013, p. 24).

Con argumentos muy similares se expresa Aguado (2014, p. 51), quien sostiene que en los supuestos en los que el sujeto conozca la procedencia delictiva o sepa que han sido transferidos para evitar su decomiso, estaríamos ante una conducta constitutiva de un delito de blanqueo de capitales a título doloso tipificada en el art. 301.1 C. P. y, en el caso de que el tercero hubiera tenido motivos para sospechar que procedían de una actividad ilícita o que eran transferidos para evitar su decomiso, estaríamos ante un delito de blanqueo de capitales imputable a título de imprudencia (art. 301.3 C. P.).

Además, existe abundante jurisprudencia sobre los bienes que el tercero haya adquirido de forma dolosa o imprudente, esto es, aquellos que para evitar su decomiso son fruto de un delito de blanqueo de capitales v. gr. El caso Banesto (Tribunal Supremo sentencia 867, 2002 y el caso Ballena blanca, sentencia 200, 2001, entre otras), con la particularidad de que, en estos supuestos, el tercero era una persona jurídica. Aun cuando no se logre demostrar la mala fe del tercero en la adquisición y se le halle exento de responsabilidad penal, el mismo está obligado a restituir lo recibido a título lucrativo: "[e]l que por título lucrativo hubiere participado de los efectos de un delito, está obligado a la restitución de la cosa o al resarcimiento del daño hasta la cuantía de su participación" (art. 122 C. P.). De la anterior descripción se puede vislumbrar que se trata de una responsabilidad objetiva frente a los presupuestos que se establecen en el tipo penal de enriquecimiento sin causa y esta responsabilidad es sistemáticamente diferente a la del tercero.

En Colombia, conforme a la legislación vigente, existe un mayor abanico de posibilidades a efectos de imputar responsabilidad penal al tercero de mala fe. En primer lugar, puede ser sancionado por un delito de testaferrato (art. 326 C. P.); no obstante, se establece un requisito inexorable para su aplicación, consistente en que el verdadero titular de los bienes haya sido condenado por un delito de 
narcotráfico y conexos y dicha sentencia se encuentre en firme. Ante la ausencia de dicho presupuesto, se dará aplicación a lo dispuesto en el art. 323 C. P., es decir, el agente será imputado por lavado de activos, siempre que el delito haga parte del catálogo de delitos enumerado taxativamente y, en su defecto, se estaría frente a una receptación (art. 447 C. P.). Este último tipo penal desempeña un papel residual frente a los dos primeros, cuya función consiste, aunque con menor severidad punitiva, en sancionar aquellas conductas que no pueden ser alcanzadas por los delitos de testaferrato o lavado de activos.

\section{El decomiso frente al titular registral: la doctrina de levantamiento del velo}

Esta construcción académica no es una figura jurídica natural del ordenamiento jurídico español, ella es extrapolada del Common Law anglosajón -Disregards (correr el velo)- y del derecho alemán Durchgriff (penetración a través de) (Pérez, 2012, p. 2). Según los registros documentales, la primera vez que se aplicó esta doctrina fue en el caso Bank of the United States vs. Deveaux (1809), instruido por el reconocido juez Marshall y su empleo estuvo motivado, fundamentalmente, por el ánimo de preservar la jurisdicción de los Tribunales Federales por encima de las sociedades, ya que ellas no podían ser consideradas como ciudadanos miembros de ningún Estado, al tratarse de una mera entidad legal con capacidad de actuar en el tráfico.

Su finalidad consiste en anular la posibilidad de que el falso titular pueda alegar la separación de patrimonios de la persona jurídica por razón de tener personalidad jurídica, cuando tal separación es, en realidad, una ficción que pretende obtener un fin fraudulento, por ejemplo, incumplir un contrato, eludir la responsabilidad contractual o extracontractual, aparentar insolvencia, etc.

Dicho esto, cabe señalar que se trata de dos supuestos claramente identificables: el primero, es que el falso titular del bien sometido al decomiso no tiene la condición de tercero en los términos que señala el art. 127 quater C. P.; y, el segundo, supone que el derecho penal, a diferencia de otras ramas del ordenamiento jurídico, no busca la verdad formal sino la verdad material (Tribunal Supremo, 2006). Así, es perfectamente válido aplicar la doctrina del levantamiento del velo cuando sea necesario dejar en evidencia entidades ficticias (personas jurídicas) creadas o utilizadas para dar cobertura a situaciones patrimoniales ilícitas.

Con base en lo anterior, no puede alegarse la separación de patrimonios de una persona jurídica y una persona física cuando, en realidad, son lo mismo, si con el desdoblamiento de personalidad se persigue un fin fraudulento (Choclán, 2001, p. 62). Por ende, no se genera ope legis la adquisición del derecho de propiedad.

Es una doctrina que, desde su génesis, está prevista, principalmente, para los supuestos de titularidad aparente y fraudulenta mediante $\mathrm{o}$, a través de las personas jurídicas; sin embargo, dicha connotación no es óbice para que pueda aplicarse a las personas físicas tal y como lo señala el Tribunal Supremo cuando sostuvo: 
[1]a sentencia combatida aplica la teoría del levantamiento del velo y prescindiendo del ropaje jurídico en la forma de adquisición trasciende de la realidad jurídica aparente a la real, declarando y poniendo al descubierto la verdadera situación en aras a la realización de la justicia material, en su dimensión patrimonial (Tribunal Supremo, sentencia 717, 2002).

Tratándose de bienes muebles, su inscripción en determinados registros públicos es un trámite de carácter administrativo que manifiesta una titularidad aparente que puede no corresponderse con la realidad y dicha condición no puede ser un obstáculo para el decomiso cuando quede demostrado que pertenecen al autor o partícipe del delito (Martín, 2005, p. 251); a este respecto, véase el Auto 125, 2000 del Tribunal Constitucional. Por su parte, la sentencia 2930 de 2000 (Tribunal Supremo, 2000, RA 2930), desestimó el recurso frente al comiso de un camión que el acusado dice es propiedad de su hermano, pues no consta que dicho camión fuera propiedad de una persona diferente de quien en los hechos de autos lo conducía y lo utilizó para transportar el hachís objeto de la sanción. Por consiguiente, si no se está ante una persona distinta a los responsables de la infracción, no habrá impedimentos para proceder al decomiso. Así mismo, la jurisprudencia señala que la titularidad administrativa no otorga la condición de tercero de buena fe (Tribunal Supremo, sentencia 798, 2008), en tanto que el registro es un trámite administrativo y no civil.

De idéntica manera, la posesión de los bienes muebles crea una apariencia de titularidad y, a su vez, otorga un efecto legitimador que es difícil de destruir: "[1] a posesión de los bienes muebles, adquirida de buena fe, equivale al título. Sin embargo, el que hubiese perdido una cosa mueble o hubiese sido privado de ella ilegalmente podrá reivindicarla de quien la posea" (art. 464 C.C.). De esta forma, cabe mencionar que la condición de titular es una cuestión independiente y nada tiene que ver con la buena o mala fe que haya operado en la adquisición de la cosa y en nada impide ejecutar la medida cuando haya lugar.

Con respecto a bienes inmuebles la doctrina del levantamiento del velo se aplica de forma análoga: si bien existe un principio de legitimación registral que confiere una presunción de titularidad "a todos los efectos legales" (art. 38 de la ley hipotecaria, en adelante LH), no obstante se trata de una presunción iuris tantum, es decir, que admite prueba en contra y puede ser desvirtuada mediante pruebas suficientes $y$, en caso de ser necesario, con audiencia del titular registral.

A su turno, el art. 34 LH, expresa:

El tercero que de buena fe adquiera a título oneroso algún derecho de persona que en el Registro aparezca con facultades para transmitirlo, será mantenido en su adquisición, una vez que haya inscrito su derecho, aunque después se anule o resuelva el del otorgante por virtud de causas que no consten en el mismo Registro. La buena fe del tercero se presume siempre, mientras no se pruebe que conocía la inexactitud del Registro [...].

Este texto se basa en el denominado principio de fe pública registral, también llamado 'tercero hipotecario', que consiste en que se debe tener por existentes y vá- 
lidos los derechos inscritos en el Registro de la Propiedad en los siguientes supuestos: primero, que posea la condición de tercero, es decir, que no sea un testaferro $\mathrm{y}$, segundo, que los haya adquirido de buena fe, o sea, ignorando cualquier vicio que pudiese invalidar la adquisición. Este principio no protege al testaferro que ostenta un título formal o aparente, pues "[1]a inscripción no convalida los actos o contratos que sean nulos con arreglo a las leyes" (art. 33 LH). En otras palabras, el negocio subyacente será nulo, siendo los bienes adjudicados al Estado atendiendo a lo dispuesto en los arts. 6.3 ("Los actos contrarios a las normas imperativas y a las prohibitivas son nulos de pleno derecho, salvo que en ellas se establezca un efecto distinto para el caso de contravención") y 1305 CC:

Cuando la nulidad provenga de ser ilícita la causa u objeto del contrato, si el hecho constituye un delito o falta común a ambos contratantes, carecerán de toda acción entre sí, y se procederá contra ellos, dándose, además, a las cosas o precio que hubiesen sido materia del contrato, la aplicación prevenida en el Código Penal respecto a los efectos o instrumentos del delito o falta [...].

Aunado a lo anterior, y en relación con los bienes inscritos a nombre de terceros, el último párrafo del art. 20 LH, incorpora una medida cautelar, la cual establece que en los procedimientos criminales podrá tomarse anotación de embargo preventivo o de prohibición de disponer de los bienes, como medida cautelar, cuando, a juicio del juez o tribunal, existan indicios racionales de que el verdadero titular de los mismos es el imputado, más allá de la mera formalidad del registro, haciendo constar dicha referencia en el mandamiento.

Esta previsión es más que acertada y es una verdadera garantía para los terceros de buena fe toda vez que, por una parte, permite asegurar el bien a decomisar dejando su libre disposición al Estado y, por otra, evita que terceros de buena fe puedan incurrir en algún vicio que eventualmente pueda invalidar la adquisición del bien, llegando a encontrarse con desagradables sorpresas. Aunque en la práctica, excepcionalmente, aquella observación en el Registro a la Propiedad se produce de forma tardía por no haberse logrado enervar la falsa apariencia y, por ende, determinar con grado de certeza que el titular real es el acusado (testaferro), no obstante, dicha cuestión no logra empañar su función preventiva.

En Colombia, también se aplica esta doctrina en los casos de titularidad aparente. El levantamiento del velo corporativo es un fenómeno que solo puede darse cuando la ley expresamente lo establece y los asociados al suscribir un determinado contrato societario se adhieren a las normas legales o estatutarias que lo rigen, aceptando que tal situación pueda acontecer (Cámara de Comercio de Bogotá et al, 1998, p. 33). En ese sentido, la Ley 190 de 1995 ‘Estatuto Anticorrupción', establece que: "[1]as autoridades judiciales podrán levantar el velo corporativo de las personas jurídicas cuando fuere necesario determinar el verdadero beneficiario de las actividades adelantadas por ésta" (art. 44).

Esta construcción no ha tenido en el país, el desarrollo normativo que se esperaba, pues sus disposiciones son lacónicas y un tanto ambiguas y obsoletas en 
comparación con la regulación española; no obstante, ello obedece a que se trata de una institución jurídica concebida para ir más allá de las meras formalidades y detectar fraudes mediante las personas jurídicas o empresas 'fachada' y dedicadas a actividades ilegales. Pero no podía ser de otra manera habida cuenta de que en España, a diferencia de Colombia, desde el año 2010 y 2015 se incorporó al C. P. la responsabilidad penal de las personas jurídicas, lo cual también hicieron Francia en 1994, Chile en 2009 y, recientemente, México y Ecuador en 2014. En Colombia, esta posibilidad parece ser una realidad lejana.

\section{Conclusiones}

Es evidente que la recuperación de activos ilícitos da suficiente muestra de ser un mecanismo idóneo para luchar contra la delincuencia organizada con fines lucrativos. Así las cosas, de un lado, Colombia aplica la figura de la extinción de dominio traída del derecho anglosajón y adaptada a la normativa interna; $\mathrm{y}$, del otro, España opta por desarrollar y extender el objeto del decomiso y sin aludir a la naturaleza jurídica de cada una de las figuras señaladas. Lo relevante, sin embargo, es que ambas persiguen un propósito común: atacar el patrimonio criminal.

En el caso de Colombia, nada hay que objetar a la aplicación sistemática de la acción de extinción de dominio en los ámbitos sustancial o procesal porque, aunque sus disposiciones puedan ser consideradas desproporcionadas, lo cierto es que resultan pertinentes de cara a la nueva realidad del país.

Respecto de España, puede afirmarse que el art. 127 quater C. P. es, sin lugar a dudas, una herramienta jurídica eficaz en la lucha contra la delincuencia económica, la corrupción y el crimen organizado; por ello, su nueva regulación es bienvenida, teniendo en cuenta que los bienes que han salido del patrimonio del acusado de forma ficticia no pueden ser alcanzados por el decomiso directo ni el ampliado y que, además, reduce considerablemente el campo de acción de los delincuentes. Sin embargo, tal y como quedó previsto, está lejos de cumplir a cabalidad con el objetivo trazado.

Las razones por las cuales se afirma lo anterior son plurales: en primer lugar, por cuanto mira con los efectos e instrumentos surge una primera duda en relación con la perturbadora y genérica remisión 'a los artículos anteriores'. En ese sentido, el apartado segundo del artículo precedente (art. 127 ter C. P., relativo al decomiso sin sentencia), dispone que el decomiso que no esté motivado en una condena únicamente "podrá dirigirse contra quien haya sido formalmente acusado o contra el imputado con base en los indicios racionales de criminalidad" (art.127 ter C. P.). En segundo lugar, sostiene que si se ha realizado una transmisión de bienes a título gratuito, es difícil determinar la desproporción entre el valor de los bienes y los ingresos lícitos del condenado. Asimismo, amplía notablemente el sujeto pasivo del decomiso que, hasta entonces, solo podía ser el responsable de la infracción (Vidales, 2015, p. 403).

La concurrencia del dolo o de la imprudencia en el decomiso desdibuja su verdadera naturaleza como consecuencia accesoria, toda vez que, una vez se hayan 
probado la certeza o la sospecha del tercero sobre la ilicitud de los bienes, dicho sujeto será responsable de un delito de blanqueo de capitales (art. 301.1.3 C. P.) a título doloso o imprudente, según sea el caso y, de resultar condenado, procede afectar los bienes por la vía de decomiso basado en condena, el ampliado o por valor equivalente.

El actual art. 127 quater C. P. está concebido como un delito de resultado, pues exige como conducta típica la transferencia del bien y, consecuentemente, constituirse en un titular aparente, por lo cual resulta criticable que la aplicación del decomiso de bienes de terceros se condicione a la previa existencia de una transmisión, existiendo tan sólo una titularidad de hecho o la posesión por el tercero del bien que es objeto, instrumento o producto del delito.

El decomiso de bienes por un valor equivalente, debería suprimirse del art. 127 quater C. P., en virtud de que se trata de una modalidad de decomiso autónoma recogida en un artículo aparte; no es de buen recibo que el legislador, buscando una mayor eficacia de las disposiciones, incurra en repeticiones inútiles que poco o nada contribuyen a los fines trazados con la nueva reforma. El art. 127 quater C. P., tal y como quedó tras la reciente reforma de 2015 al Código Penal, constituye una extensión o, por lo menos, una nueva redacción del delito de blanqueo de capitales -doloso e imprudente- recogido en el art. 301.1.3 C. P.

Con base en lo expuesto, una propuesta de lege ferenda para el caso español es la de fijar el límite de los supuestos del art. 127 quater C. P. de una forma diáfana que disipe la actual ambigüedad de su texto y, además, separar el decomiso del C. P., prescindiendo de tantas formalidades técnicas que no hacen más que dificultar la persecución del patrimonio criminal.

De igual forma, una propuesta de lege ferenda para Colombia, supone admitir que, en términos generales, la legislación actual resulta bastante buena, sobre todo, si se la compara con la de otros países -España, por ejemplo-, para eliminar cualquier ventaja patrimonial que provenga del delito; sin embargo, presenta falencias que se deben superar con urgencia, en particular, lo atinente a la implementación de la responsabilidad penal de las personas jurídicas. Hasta tanto ello suceda, no puede hablarse de una verdadera reforma en la lucha contra la delincuencia económica y el crimen organizado. Lo anterior, sumado al necesario aumento de los jueces de extinción de dominio, porque, en un país como el nuestro, con la coyuntura que atraviesa por la proliferación de la delincuencia organizada, tener solamente tres jueces resulta ser un despropósito.

\section{Referencias}

Aguado, T. (2000). El comiso. Madrid: Edersa.

Aguado, T. (2013). Embargo preventivo y comiso en los delitos de tráfico de drogas y otros delitos relacionados: presente y ¿futuro?, Estudios Penales y Criminológicos (XXXIII), 265-320. 
Aguado, T. (2014). Comiso: crónica de una reforma anunciada. Análisis de la Propuesta de Directiva sobre embargo y decomiso de 2012 y del Proyecto de reforma del Código Penal de 2013. Indret, 1-56. Recuperado de http:/ /www. indret.com/pdf/1025.pdf.

Auto 125 (2000). Tribunal Constitucional español.

Auto 10467 (1996, junio 14). M.P. Ricardo Calvete Rangel. Sala de Casación Penal. Corte Suprema de Justicia.

Ayo, M. (1997). Las penas, medidas de seguridad y consecuencias accesorias. Pamplona: Aranzadi.

Bacigalupo, S. y Bajo, M. (2010). Derecho penal económico (2 ed.). Madrid:Universitaria Ramón Areces.

Blanco, I. (2007). La aplicación del comiso y la necesidad de crear mecanismos de recuperación de activos. Revista electrónica de la Asociación Internacional de Derecho Penal (1). Recuperado de http://www.penal.org/sites/default/files/ files/BlancoA1.pdf

Cámara de Comercio de Bogotá et al (1998). La extinción de dominio y el registro mercantil. Bogotá: Cámara de Comercio de Bogotá.

Campos, D. (2015). Decomiso, medidas cautelares y recuperación de activos. Recuperado de https://www.fiscal.es/fiscal/PA_WebApp_SGNTJ_NFIS/descarga/ PESCRITA_CAMPOS.pdf?idFile=95c18c33-4eba-4595-846c-9ff5ea2cfcc6

Caso Bank of the United States vs. Deveaux (1809). Suprema Corte de EUA.

Caso Welch vs. Reino Unido. (1995, febrero 9). Tribunal Europeo de Derechos Humanos.

Caso Jamil vs. Francia. Sentencia (junio 9, 1995). Tribunal Europeo de Derechos Humanos.

Cerezo, A. (2004). Análisis jurídico-penal de la figura del comiso. Granada: Comares.

Choclán, J. (2001). El patrimonio criminal "comiso y pérdida de la ganancia". Madrid: Dikynson.

Consejo de la Unión Europea (1990). Convenio 141 del Consejo de Europa.

Consejo de la Unión Europea (2001). Decisión Marco 2001/500/JAI, relativa al "blanqueo de capitales, la identificación, seguimiento, embargo, incautación y decomiso de los instrumentos y productos del delito"

Consejo de la Unión Europea (2005). Decisión Marco 2005/212/JAI de 24 de febrero relativa al "decomiso de los productos, instrumentos y bienes relacionados con el delito". Estrasburgo el 8 noviembre 1990, sobre blanqueo, seguimiento, embargo y decomiso del producto de los delitos. 
Corcoy, M. (2015). Comentarios al Código Penal. Valencia: Tirant lo Blanch.

Cuello, J. y Mapelli, B. (2015). Curso de Derecho Penal, Parte General (3 ed.) Madrid: Tecnos.

De Almeida, M. (2005). Buena fe objetiva y los deberes de ella derivados, Tratado de la buena fe (T II). Buenos Aires: La Ley.

Decreto 050 de 1987. Por el cual se expide el Código de Procedimiento Penal. Diario Oficial No. 37754, Congreso de la República de Colombia, 13 de enero de 1987.

Decreto 100 de 1980. Por el cual se expide el nuevo Código Penal. Diario Oficial No. 35461, Congreso de la República de Colombia, 23 de enero de 1980.

Decreto 2700 de 1991, Por el cual se expiden las normas de procedimiento penal. Diario Oficial No. 40910, Congreso de la República de Colombia, 30 de noviembre de 1991.

Díez-Ripollés, J. L. (2015). Derecho Penal, Parte General (4 ed.) Valencia: Tirant lo Blanch.

Diez-Picazo, L. (1988). Sistema de Derecho Civil (T. I, 6 ed.), Madrid: Tecnos.

Fiscalía General del Estado (2010). Circular n 4/2010, Sobre las funciones del fiscal en la investigación patrimonial en el ámbito del proceso penal.

García-Pablos, A. (2005). Introducción al derecho penal. Madrid: Centro de Estudios Ramón Areces.

Garzón, F. (2003). Instituciones de Derecho Procesal Penal (4 ed.) Bogotá: Legis.

Gascón, F. (2007). El decomiso transfronterizo. Madrid: Colex.

Gracia, L., Boldovar, M. y Alastuey, M. (2004). Lecciones de consecuencias jurídicas del delito (3 ed.). Valencia: Tiran lo Blanch.

Hava, E. (2015). Comentario a la reforma penal de 2015. Navarra: Aranzadi.

Iguarán, M y Soto, W. (2015). La extinción de dominio y los terceros de buena fe exento de culpa. Bogotá: Ediciones Jurídicas Andrés Morales.

Jaén, M. y Perrino, A. (2015). Recuperación de activos derivados del delito: un objetivo prioritario de la reforma penal. La ley (8545).

Jescheck, H. y Weigend, T. (2003). Tratado de derecho penal, parte general (5 ed.). Granada: Comares.

Lara, M. (2004). Extinción de dominio. Bogotá: editorial carrera 7.

Ley 95 de 1936. Por la cual se expide el Código Penal. Diario Oficial No. 23160. Congreso de la República de Colombia, abril de 1936. 
Ley 94 de 1938. Por la cual se expide el Código Penal. Diario Oficial No. 23801. Congreso de la República de Colombia, junio de 1938.

Ley 2 de 1984. Nueva ley de administración de justicia. Diario Oficial No. 23095. Congreso de la República de Colombia, enero de 1984.

Ley 81 de 1993. Por la cual se introducen modificaciones al Código de Procedimiento Penal. Diario Oficial No. 41098. Congreso de la República de Colombia, julio de 1993.

Ley 333 de 1996. Por el cual se establecen las normas de extinción de dominio sobre los bienes adquiridos de forma ilícita. Diario Oficial No. 42945. Congreso de la República de Colombia, diciembre de 1996.

Ley 599 de 2000. Por la cual se expide el Código Penal. Diario Oficial No. 44097. Congreso de la República de Colombia, julio de 2000.

Ley 600 de 2000. Por la cual se expide el Código de Procedimiento Penal. Diario Oficial No. 44097. Congreso de la República de Colombia, julio de 2000.

Ley 793 de 2002. Por la cual se deroga la Ley 333 de 1996 y se establecen las reglas que gobiernan la extinción de dominio. Diario Oficial No. 45046. Congreso de la República de Colombia, diciembre de 2002.

Ley 906 de 2004. Por la cual se expide el Código de Procedimiento Penal. Diario Oficial No. 45658. Congreso de la República de Colombia, septiembre de 2004.

Ley 890 de 2004. Por la cual se modifica y adiciona el Código Penal. Diario Oficial No. 45602. Congreso de la República de Colombia, julio 2004.

Ley 1708 de 2014. Por medio de la cual se expide el Código de Extinción de Dominio. Diario Oficial No. 49039. Congreso de la República de Colombia, enero de 2014.

López, D. \& García, M. (1996). El Código Penal de 1995 y voluntad del legislador. Comentario al texto y al debate parlamentario. Madrid: [s.n.].

Luzón, D. (2004). Curso de Derecho penal. Parte General. Madrid: Universitas.

Mapelli, B. (1998). Las consecuencias accesorias en el nuevo código penal. Revista penal (1), 43-54.

Martín, J. (2005). El comiso de propiedad de bienes de "tercero": análisis del respeto de las garantías sobre la titularidad por las sentencias penales (A propósito del auto TC 125/200, de 19 de abril). Derecho privado y constitución (19), 225-258.

Mir, S. (2015). Derecho Penal, Parte General (10 ed.) Barcelona: Reppertor.

Muñoz, F. y García, M. (2010). Derecho Penal, Parte Especial. Valencia: Tirant lo Blanch.

Octavio de Toledo y Ubieto, E. (2002). El comiso. La Ley (3), 1563-1569. 
Ospino, J. (2004). Extinción de dominio. Bogotá: Editorial carrera 7.

Pérez, B. (2012). Levantamiento del Velo y Responsabilidad Tributaria. Revista de información fiscal, (110), 33-72 Recuperada de https://rua.ua.es/dspace/ bitstream / 10045 / 43775 / 1 / INFORMACION\%20FISCAL \% 20110\% 20 Levantamiento\%20del\%20velo\%20y\%20responsabilidad\%20tributaria.pdf

Pinilla, N. (1998). Nuevos instrumentos Contra el Lavado de Activos. Ponencia presentada en la Cámara de Comercio de Bogotá, Bogotá, Colombia.

Plazas, L. (2004). Extinción de dominio. Bogotá: Editorial carrera 7.

Prats, F., Morán, C. y Quintero, G. (Dir.). (2001). Comentario al nuevo código penal, Navarra: Aranzadi.

Restrepo, M. (2006). Instrumento cautelar del comiso. Estudios Socio-Jurídicos (2), 151- 170.

Reino de España. Ley Orgánica 1 de 2015. Por la que se modifica la Ley Orgánica 10/1995, de 23 de noviembre, del Código Penal. BOE No. 77. Congreso de los Diputados, marzo de 2015.

Ríos, J. (2011). Las penas y su aplicación. Madrid: Colex.

Roig, M. (2016). La regulación del comiso: el modelo alemán y la reciente reforma española. Estudios Penales y Criminológicos 36, 199-279.

Roma, A. (Dir.) et al. (2015). Código penal comentado. Barcelona: Bosch.

Sentencia 2930 (2000, abril 10) (RA. 2930). Tribunal Supremo.

Sentencia 200 (2001, marzo 31). Tribunal Supremo.

Sentencia 155 (2002, julio 22). Tribunal Supremo.

Sentencia 867 (2002, julio 29). Tribunal Supremo.

Sentencia 717 (2002, octubre 18) (R.A. 1074/2004). Tribunal Supremo.

Sentencia 135 (2003 junio 30). Tribunal Constitucional.

Sentencia 1074 (2004, octubre 18) (R.A. 6559). Tribunal Supremo.

Sentencia 952 (2006, octubre 6) (R.A. 5739). Tribunal Supremo.

Sentencia 798 (2008, noviembre 12) R.A. 6366). Tribunal Supremo.

Sentencia (2009, enero 27) (RA: 2009/130). Tribunal Supremo.

Sentencia (2011, febrero 1) (RA: 2011/ 353). Tribunal Supremo.

Sentencia 600 (2012, julio 12) (RA: 2012/ 5571). Tribunal Supremo. 
Sentencia 1778 (2013, marzo 5) (R.A. 2014/38791). Tribunal Supremo.

Sentencia 852 (2013 diciembre 18). Tribunal Supremo.

Sentencia 969 (2014, febrero 18). Tribunal Supremo.

Sentencia 1008 (2014, marzo 5). Tribunal Supremo.

Sentencia T- 460 (1992, julio 15). Acción de Tutela. MP. José Gregorio Hernández Galindo. Corte Constitucional.

Sentencia C-176 (1994, abril 12). Demanda de Inconstitucionalidad. M.P. Alejandro Martínez Caballero. Corte Constitucional.

Sentencia C-540 (1995, mayo 26). Demanda de Inconstitucionalidad. M.P. Jorge Arango Mejía. Corte Constitucional.

Sentencia C-319 (1996, julio 18). Demanda de Inconstitucionalidad. M.P. Vladimiro Naranjo Mesa. Corte Constitucional.

Sentencia C-374 (1997, agosto 13). Demanda de Inconstitucionalidad. M.P. José Gregorio Hernández Galindo. Corte Constitucional.

Sentencia C-409 (1997, agosto 28). Demanda de Inconstitucionalidad. M.P. José Gregorio Hernández Galindo. Corte Constitucional.

Sentencia C-1007 (2002, noviembre 18). Demanda de Inconstitucionalidad. M.P. Clara Inés Vargas Hernández. Corte Constitucional.

Sentencia (2012, febrero 8). Tribunal Superior de Bogotá, Sala de Extinción de dominio.

Sentencia (2001, mayo 3). Consejo de Estado, Sala de lo Contencioso Administrativo, Sección Tercera.

Sentencia (2002,enero 24).ConsejodeEstado,Sala deloContencioso Administrativo, Sección Tercera.

Unión Europea (2014). Directiva 2014/42/UE, sobre "Embargo y el decomiso de los instrumentos y del producto del delito en la Unión Europea". 